Article

\title{
Accounting for Carbon Footprint Flows in Wine Production Process. Case Study in Spanish Winery
}

\author{
Miguel Marco-Fondevila *(D), José M. Moneva (D) and Fernando Llena-Macarulla \\ Department of Accounting and Finance, University of Zaragoza, 50005 Zaragoza, Spain; \\ jmmoneva@unizar.es (J.M.M.); fllena@unizar.es (F.L.-M.) \\ * Correspondence: mmarcof@unizar.es
}

Received: 27 October 2020; Accepted: 24 November 2020; Published: 25 November 2020

\begin{abstract}
Companies are gradually becoming conscious about the necessity of reducing their environmental impact and adopting low-carbon strategies in order to cope with increasing institutional and social demands. However, remaining competitive while reducing the environmental impact and improving the corporate image requires adopting sophisticated mechanisms boosting eco-efficiency and keeping costs tight. Material Flows Cost Accounting (MFCA) is an instrument that allows the monitoring of, measurement of, and accounting for physical and monetary processes along the production process. If extended to the supply chain, and applied to the energy usage and $\mathrm{CO}_{2}$ emissions, it allows one to account for the Carbon Footprint (CF) of a company and its products at any given stage of the value chain. The current paper presents a case study developed under the framework of a three-year project to introduce an energy use and carbon emissions monitoring and accounting system in a large winery company in Spain, based on the MFCA approach and CF accountability. Including the supply chain of the company and the whole farming cycle of its main input, the case study presents the method and phases adopted to implement the project, its direct and indirect results and outcomes, and the conclusions that can be extracted, which may be inspirational for practitioners and scholars envisaging similar projects.
\end{abstract}

Keywords: winery; MFCA; carbon footprint; environmental impact

\section{Introduction}

Over the years, sustainable development has become an increasingly relevant matter for companies, which need to find the right balance between being competitive, having a good corporate reputation and finding innovative ways to be more eco-efficient, extending their primarily economic goals to ecological and social goals [1]. As a consequence, efficient environmental management becomes a priority for companies, together with coping with the increasing interest of society in the ecological impact of companies. In this regard, the reduction in $\mathrm{CO}_{2}$ emissions, as one of the main causes of Climate Change, has become a relevant topic for companies.

As part of Environmental Management Assessment (EMA), the Material Flow Cost Accounting (FLCA) approach can support companies in promoting environmental management and accounting systems that target a low-carbon economy [2]. Furthermore, its focus on the physical and monetary flows along the production activity allows to include the supply chain in the system, thus permitting to calculate the carbon footprint of the company and its products. The use of Material Flows Cost Accounting (MFCA) does also provide transparency and information for making decisions about the environmental impacts of the company [3], as well as better coordination and communication about energy usage in the organization [4]. As concluded by Nakajima et al. [2], MFCA simultaneously supports the reduction in environmental impact and costs, while making it possible for the company to significantly reduce purchasing costs, as long as collaboration and understanding prevail between the 
company and its suppliers. The company developing MFCA may act as promoter and leader among its suppliers as well as an information intermediary between its customers and its suppliers [2,5], introducing the idea of Life Cycle Assessment (LCA).

As part of the farming sector, the wine industry has a close relationship with the environment which has been addressed in many studies with different focuses [6-10], the carbon footprint measurement and labelling being one of the most important ones [11-15].

In most cases, the increase in production, quality and competitiveness undergone by the wine sector over the years has unfortunately been reached at the expense of reducing the sustainability of traditional production processes. Within the farming sector, emissions from industrial wastewater (calculated from activity data of dairy, swine, slaughterhouse, citric, sugar, and wine sectors), are supposed to increase by $58 \%$ from 2000 to 2030 [16]. Wine is no exception [17] since all the related activities require the provision of materials and energy [10] that contribute to resource depletion and a variety of environmental emissions [18]. In fact, the amount of energy and materials required for wine production has increased considerably due to the higher consumption of water and plant treatments in the vineyards, the enlarged amount of bottled wine, the limited use of returnable bottles, the widespread use of industrial cooling equipment and the intensification in transport costs from exports.

On the other side, customers are gradually adding the environmental friendliness as a strong criterion when choosing their wine in the marketplace and many wineries are devoting efforts to a more eco-efficient production, making it necessary to design a system to measure and solve the potential problems [19]. At present, the wine sector is one of the industries under increasing pressure to adopt new approaches towards environmental assessment and the reporting of product-related greenhouse gas emissions [20-22]. Impacts on the regional economy have been subjected to analysis [23] as issues related to the wine sector sustainability $[19,22]$.

In this scenario, where the most relevant environmental impact of the wine production process is caused by energy consumption and $\mathrm{CO}_{2}$ equivalent emissions, carbon footprint (CF) can be pointed out as an appropriate sustainability indicator to be utilized in the winery decision-making. As such, this paper presents a case study focused on a large winery in Spain where a project was implemented to adopt a monitoring and accounting system for $\mathrm{CO}_{2}$ emissions along the whole industrial process, including the supply chain. From an MTCA approach, the company applied a system to account for the energy usage and $\mathrm{CO}_{2}$ emissions of its products at every stage of production, thus allowing the improvement of efficiency, costs savings and innovation, as well as labelling of the company products with the corresponding unitary $\mathrm{CF}$.

With these premises, this paper objective is to model the CF of a winery for different types of wine products to be integrated into the management control, including its supply chain, from an LCA and MFCA approach that will relate the monetary and carbon emissions flows at every stage of the productive process.

The paper presents the case study, from its antecedents to the outcomes achieved, as a relevant experience that could serve as guidance and inspiration for other winery companies and, in general, for farming sector companies looking to implement accounting and monitoring systems to reduce their $\mathrm{CF}$ and environmental impact.

\section{Background}

\subsection{Material Flow Cost Accounting}

Over the years, companies have become more and more aware of the need to address sustainability not only as a way to respond to society pressure, but also as a means to be more efficient and clean. Efficient environmental management must align with public awareness and political programs and promote systems that target a low-carbon economy [2]. Indeed, reducing $\mathrm{CO}_{2}$ emissions is a priority goal for companies since it reduces their environmental impact while decreasing variable costs in energy consumption, thus improving economic and environmental performance [24]. 
Material Flow Cost Accounting (MFCA) has gained relevance over the years as a tool supporting eco-efficient decisions [4], with its combined focus on environmental and monetary flows. As part of the Environmental Management Assessment (EMA) discipline developed in the 1990s [9], MFCA is one of its most fundamental and well-developed tools [25], defined as a "tool for quantifying the flows and stocks of materials in processes or production lines in both physical and monetary units" [26]. Standardized with ISO 14051, MFCA has also been considered to have high potential to measure and account for carbon emissions along companies supply chain [2,27], and to generate information about the physical and monetary flows on a routine basis [4]. The physical flows have a strong focus on materials and energy flows, since their use is directly connected to many of the environmental impacts of the company, but it is also a major driver of purchase cost [28]. Citing Christ and Burritt [4], "it can be argued the effective management of material and energy flows constitutes an important undertaking for contemporary organisations, both economically and environmentally". From that premise, MFCA provides a system to improve eco-efficiency and to make it more clearly understood and articulated [29].

Considering the increased need to provide information about the company performance concerning its environmental impacts, the development of MFCA improves the transparency of material flows and energy consumption in companies, allowing for better decisions [3], and more internal coordination and organization [30]. As concluded by Nakajima et al. [2], MFCA is a method that simultaneously helps to reduce environmental impacts and costs, provided that there is collaboration between the company and its suppliers, as a first step towards a low-carbon supply chain.

Indeed, reducing the environmental impact and related costs implies looking at the company's own process as well as the inputs coming through the supply chain. While losses or inefficiencies within the company process might be studied and improved in the short-term, the changes related to the environmental impact of inputs may require communication and collaboration in a medium or long-term framework. The company developing MFCA may act as promoter and leader among its suppliers, presenting the benefits of the system, as well as an information intermediary between its customers and its suppliers, so the former know about the latter performance in terms of environmental impact $[2,5]$.

\subsection{Carbon Emissions in the Wine Industry}

The wine industry forms part of the agro-food sector and, particularly, of the farming industry. As such, its relationship with the environment is intense, since its main produce comes straight from the soil. Through the years, many studies have addressed the environmental impacts of the wine industry in different geographical areas focusing on several topics such as waste [6], sustainability $[7,8]$, eco-efficiency [9], or Life Cycle Assessment (LCA) [10], among others.

Focusing on carbon emissions and energy consumption as one of the main elements of MFCA, the CF measurement for agro-food has been widely studied by a number of authors [11-15], as its importance for labelling and reporting grows worldwide.

In the wine industry, most methodologies studied are focused on savings in energy, raw materials, diminished emissions and waste generation and, in particular, on water consumption [15,31,32]. Drawing on contingency theory, the current use of water-related environmental management accounting information (here named as water management accounting) was implemented by Christ [33] to assess the long term implications associated with water management in Australian wine supply chains. However, most studies have only addressed specific methodological issues from an attributional life-cycle perspective, or have directly reported the CF profile for a given wine product, making it increasingly complex to assess market interactions linked to the entire life cycle of wine-making.

The quantification of greenhouse gas emissions often underpins the life-cycle of wine, which has also been applied to several studies [17,19,34-39] since it can be considered an adequate methodology for the accounting itself [18]. The studies that calculated the CF of different types of wine to determine the main reasons for their varying results indicate the relevance of factors such as wine ageing, optimization of inputs, harvest yields, data quality or agricultural practices (i.e., organic vs. conventional), and argue 
the difficulty in standardizing specific mechanisms for greenhouse gas emissions communication within the wine sector [15].

The conventional production system has been found to have a higher $\mathrm{CF}$ than the organic production $[17,40]$ mainly due to the agricultural and packing phases. A critical review of several methodological and conceptual issues focused on wine carbon footprint is offered by Rugani et al. [41]. Another interesting contribution to the applied measurement of CF is offered by Quezada et al. [42] who calculated the CF in a winery company using a method composed of financial accounts (called "MC3"). One of the principal outcomes obtained was demonstrating that having an appropriate determination of the CF is an important factor of competitiveness, especially in the international market, which will inevitably impose restrictions based on sustainable production.

Agricultural practices for vineyards have been included as well as the landscape conservationrelated issues as a long-term provision of a full range of ecosystems [43]. Viticulture is, in fact, the stage with the largest relative contribution to the overall environmental impact, while the bottle production is the subsequent stage, followed by its transport [17,37]. Indeed, Bosco et al. [44] showed that the vineyard-planting phase has a significant impact on the wine $C F$ and has to be considered in the life cycle. Even though it is frequently omitted in literature, the supply chain of wineries shall be studied as a significant contributor to the aggregated CF.

From a communication perspective, labelling and reporting the CF can be important drivers to promote carbon emissions measurement in organizations and their supply chain, boosting the life cycle thinking of the sector [45]. Indeed, a correlation exists between environmental disclosure and eco-innovation [46]. A number of studies have highlighted the usefulness of CF to report environmental results in the wine sector, due to its common use by stakeholders and its favorable acceptance by the general public [15]. Studies go from stating the need for a simple calculation method, understandable by all investment stakeholders, [47] to outlining examples that ensure that the CF can provide support to investment financing decisions. Besides which, the improvement of environmental characteristics of a given type of wine and its corresponding labelling could represent an important marketing strategy.

However, the extensive literature review offered by Christ and Burritt [9] reveals that practices within wine firms are still largely unexplored and often inadequate. In general terms, the lack of quantitative environmental data about operational processes and products is an important barrier to improving environmental performance of this sector. More research has to be conducted in this sense introducing "green" patterns in the conventional studies of wine consumers focused on the individual taste preferences [48].

Provided that MFCA has been described as a tool to develop environmental management activities such as investment appraisal, environmental impact assessment and short and long term environmental budgeting [49], in this paper we define carbon accounting as the recognition of the non-monetary and monetary flows of greenhouse gas emissions and energy consumption in all levels of the value chain [50], introducing control management and labelling as part of the CF accounting.

To achieve the principal aim of this study, an applied innovation project was performed in a Spanish winery company in the Region of Aragon "from the vine to the table: carbon footprint labelling of the aggregated wine production process". The case study methodology applied to this project is considered to be the more adequate for this study, deepening in the knowledge about CF in the internal management of wineries [12,51].

\section{Case Study}

\subsection{Methods}

As part of a three-year project, the case study presented refers to a large winery company in Spain with more than 70 years of history, working as a cooperative with more than 700 members who own close to 4000 hectares of vineyard. The company, which absorbs around 30 million kilos of wine grape per year, produces a wide variety of wine products in various formats and volumes, after different industrial processes. 
The company value chain has three main phases, starting with the main input farming (grape), following with the production process and storage, and ending with the distribution and selling of final products. In the first phase, depending on each year's crop, from two thirds to three quarters of the grape is produced by farmers who are members of the cooperative and, therefore, shareholders of the company. The remaining part of grape needed, together with other supplies used in the farming cycle and in the production process, are the areas where the company has less control and, therefore, more difficulties in imposing new monitoring and accounting systems for CF (Figure 1).

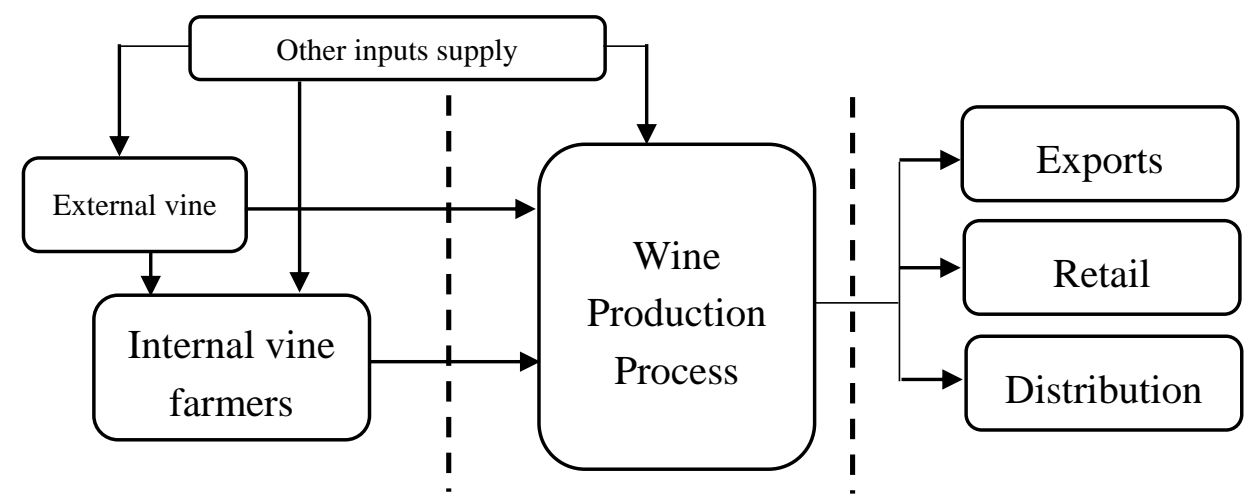

Figure 1. Value chain of the company.

One of the detected difficulties during the design of the methodology here applied was to fit the CF accounting into the traditional accounting framework of the winery. In line with the results obtained by Couto-Viana and Lima-Rodrigues [52], the Spanish wine industry is also influenced by long-lived habits that means that companies develop their own accounting practices such as a unique cost formula. The Data Envelopment Analysis used by Aparicio et al. [53] to measure and decompose inefficiency of the Spanish quality wine sector, was also considered when designing the methodology. In the proposed CF integrated method, all activities have been considered in a simplified and internally applied procedure, including all the components of wine packaging (bottle, stopper, capsule, label, boxes, pallets, etc.) because it is considered to be of high importance for the analysis [54], given that most of these impacts are related to fossil fuel emissions for the production and transport of materials [34].

The project was divided in six phases (Table 1), of which the final outcome would be the introduction of a CF monitoring, accounting and reporting system based on the MFCA approach that would permit the knowledge of the CF 'weight' of any product or semi-finished product at any given moment, and to label the final products with a CF aggregated label including the supply chain impact.

Table 1. Phases of the project.

\begin{tabular}{cl}
\hline Phase 1 & $\begin{array}{l}\text { Characterize the company value chain from a Life Cycle Analysis approach, auditing energy } \\
\text { consumption and equivalent } \mathrm{CO}_{2} \text { emissions in all processes linked to the product, in production } \\
\text { process and supply chain. }\end{array}$ \\
\hline Phase 2 & $\begin{array}{l}\text { Linkage and accrual of aggregate } \mathrm{CO}_{2} \text { emissions equivalent to the final production, obtaining the } \\
\text { volume of emissions per unit applicable to each final product unit (bottle/wine box). }\end{array}$ \\
\hline Phase 3 & $\begin{array}{l}\text { Development of an interactive online application integrating all factors of the supply and } \\
\text { production chain, allowing for real-time accounting and analysis of } \mathrm{CO}_{2} \text { emissions. }\end{array}$ \\
\hline Phase 4 & $\begin{array}{l}\text { System implementation, (1) incorporating the company technical staff, (2) cooperative farmers and } \\
\text { (3) representatives of the rest of the supply chain. Training and practice on the use and management } \\
\text { of the application. }\end{array}$ \\
\hline Phase 5 & $\begin{array}{l}\text { Complete integration of the application in the integrated management and accounting system of the } \\
\text { company, permitting the automatically linkage of } \mathrm{CO}_{2} \text { emissions with other systems such as } \\
\text { financial accounting, product card, vendor card, etc. }\end{array}$ \\
\hline Phase 6 & $\begin{array}{l}\text { Reporting of results in the communication and corporate information system, as well as the wine } \\
\text { labelling process. Public communication of aggregated emissions and volume of emissions per } \\
\text { bottle (or unit sold) on product label. }\end{array}$ \\
\hline
\end{tabular}


Taking into account the agricultural cycle and the rather seasonal component in the winery business, we considered a time horizon of a year for the LCA and CF calculation, even though the data of several years were used to establish an average and stable scenario. LCA being an analysis technique that allows the assessment of the environmental impacts (in this case the $\mathrm{CO}_{2}$ emissions) at every stage of a product's life, it is convenient to define what the ordinary scenario is in general and at every stage, so that the results obtained in a given year can be compared to standard and regular data, avoiding eccentric results. Besides, all phases of the project were developed by a team formed by researchers and company workers from different departments, so that all decisions and steps taken would make sense from the technical, productive and economic perspectives.

One of the key elements of the project was the in-house specific software implemented to instantly account for all the $\mathrm{CO}_{2}$ emissions contributions along the supply chain, in line with the software implemented by Bonamente et al. [51] for the water measurement in a winery. A similar proposal has been explored by Casini et al. [55] who proposed a specific software as a management control model to establish the winegrower's production cost for a single bottle of wine, with the ability to determine the cost differences for each product typology, even when little information was available.

The software implemented for the project counted with an on-line application which was installed in the cooperative farmers' phones, tablets or other devices so that they would be able to record any $\mathrm{CO}_{2}$ emissions or energy consumption-related activity in real time, avoiding any loss of information and efficiency, as well as reducing 'paperwork' time.

The information sent from the fields would immediately be registered and accounted in the company server, allowing not only the monitoring and aggregation of the correspondent $\mathrm{CO}_{2}$ emissions, but also the realization of any potential problems or deviations from expected. Several meetings were conducted to engage cooperative farmers and company workers in the project, and to train them in the use of the on-line application and the related software. The project flows outline is presented in Figure 2.

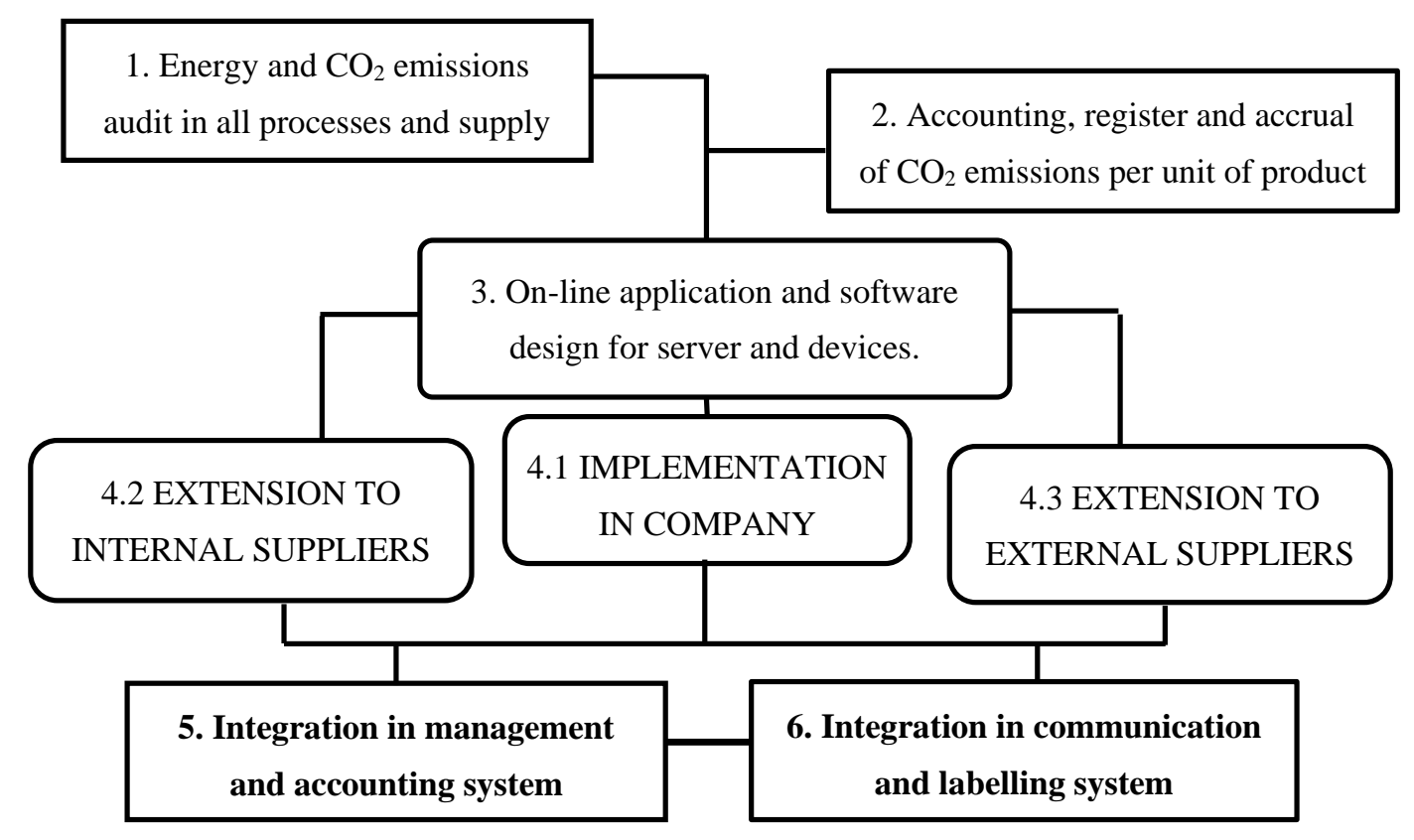

Figure 2. Project flows outline.

\subsection{Results and Outcomes}

The work performed during phases 1 and 2 allowed the visualization of the complete value chain of the company linked to $\mathrm{CO}_{2}$ emissions and energy consumption, highlighting all the relevant activities that had to be monitored, and that would imply further addition of $\mathrm{CO}_{2}$ to the final $\mathrm{CF}$ of the 
output. Additionally, inefficiencies and unexpected levels of consumption were discovered in some of the process equipment and machinery, suggesting its repair or replacement in order to save unnecessary energy costs and carbon emissions. Furthermore, the detailed identification of all activities involving energy consumption led to the consideration of potential improvements individually, which had never been taken into account when thinking of the process as a whole. The most significant activities linked to the CF of the company are shown in Figure 3.

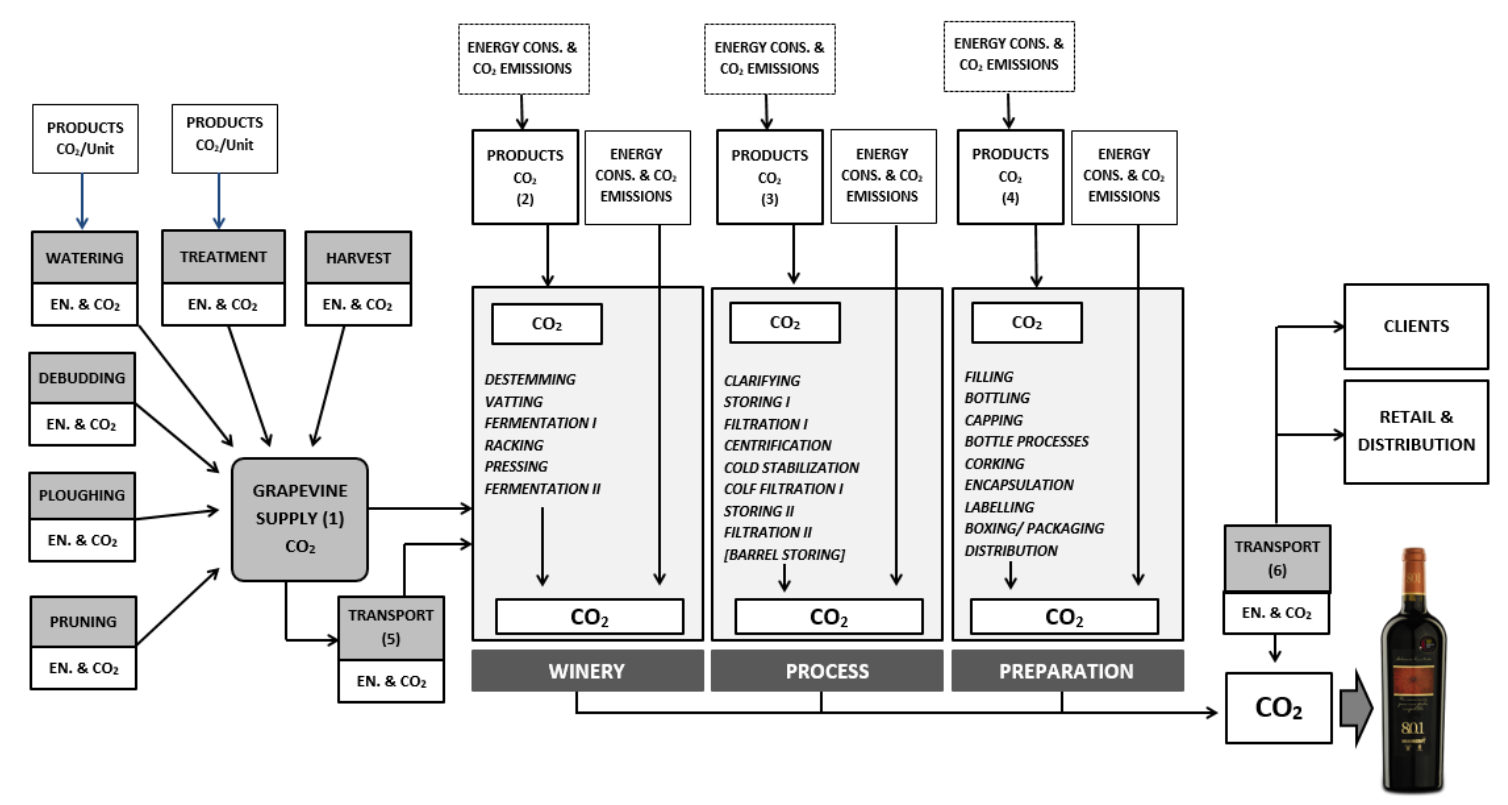

Figure 3. Description of activities linked to $\mathrm{CO}_{2}$ emissions and energy consumption.

The energy and $\mathrm{CO}_{2}$ emissions audit undertaken helped to determine not only which activities were linked to energy consumption but also their weight in terms of $\mathrm{CO}_{2}$ emissions, due to the type and volume of the energy source used. Furthermore, it allowed one to foresee potential changes in several parts of the process by shifting the conventional energy source used to a renewable or less polluting one.

The implementation of phases 3 and 4 led to the actual monitoring and accounting of energy consumption and $\mathrm{CO}_{2}$ emissions throughout the production process, by using the on-line software designed ad-hoc. The company server received real-time communication from internal suppliers (vine farmers) who, having installed the application on their phones, tablets or laptops, would record every step undertaken in their farming activity, transmitting it to the headquarters. While the latter would then have the chance to monitor the accumulated CF of input (grape) and take any measures if needed (advising farmers to change the products used, reduce their consumption, change specific patterns, etc.), the farmers would also have a record of energy consumption that will help them reduce their costs and check for inefficiencies, thus contributing further to lowering the $\mathrm{CF}$ of the company main input.

Once the process was fully implemented, the company could accurately determine the $\mathrm{CF}$ of the grape introduced in the production process, to which the $\mathrm{CO}_{2}$ from the following activities would be progressively added. As for external suppliers (not cooperative farmers), the company requested them to report on the $\mathrm{CO}_{2}$ associated with their products, so it could be registered in the production software. As a secondary consequence, some external products were replaced by new ones with lower $\mathrm{CF}$, which also contributed to reducing the overall CF. Once determined, the quantity of the different supplies used, and their respective factor identified (in $\mathrm{Kg}$ of $\mathrm{CO}_{2}$ equivalent per $\mathrm{kg}$ of material), it became possible to calculate the carbon footprint of the whole wine production process.

After phases 5 and 6 , at the end of the project, the results obtained in terms of overall carbon emissions and unitary carbon emissions, showed a significant reduction as presented in Table 2: 
Table 2. Carbon Footprint of the company and unitary.

\begin{tabular}{lccc}
\hline & Year 1-CO $\mathbf{C}$ eq. & Year 2-CO $\mathbf{C O}_{\mathbf{2}}$ eq. & Change in \% \\
\hline CF for the company and its supply chain & 12.734 tons & 10.224 tons & $-19.71 \%$ \\
\hline Average CF per unit of product (in Kg/L) & $0.828 \mathrm{~kg} / \mathrm{L}$ & $0.795 \mathrm{~kg} / \mathrm{L}$ & $-3.98 \%$ \\
\hline Average CF per 0.75 L bottle (estimated) & $0.755 \mathrm{~kg} /$ bottle & $0.731 \mathrm{~kg} / \mathrm{bottle}$ & $-3.28 \%$ \\
\hline
\end{tabular}

The success of the project was patent in the company production process, with close to a $30 \%$ decrease in $\mathrm{CO}_{2}$ emissions in the first year. As for the supply chain, the decrease was still limited, mostly due to the fact that improvements from some the efficiency measures adopted were not yet registered at this stage, having its effect in the following crop. However, even though the grape in the second year had lower contents of water and was therefore less productive than that of the previous year, the $\mathrm{CO}_{2}$ emissions per liter of final product fell by $4 \%$, exposing an overall improvement in the process. The results for following years will also depend on the grape characteristics, but new decreases are expected as farming efficiency measures are accounted in the final product.

Comparing the CF within the wine industry is both complex and delicate for several reasons. On the one hand, the different studies and works published to date have different scopes and include different activities in the LCA process. On the other hand, significant differences can be observed from one vineyard to another, especially if they belong to different countries or climatic areas. The differences linked to the grape organic characteristics, the water required, the type and timing of harvesting, etc., are added to those related to the available infrastructures in terms of type and cost of energy, water, soil, transport, etc. However, the results obtained in the project in terms of CF per bottle are in line with previous similar studies for different countries and types of wine (Table 3).

Table 3. Carbon footprint (CF) per bottle in different studies.

\begin{tabular}{cccccc}
\hline & $\begin{array}{c}\text { Scrucca et al. } \\
{[56]}\end{array}$ & $\begin{array}{c}\text { Vázquez et al. } \\
{[\text { [15] }}\end{array}$ & $\begin{array}{c}\text { Rinaldi et al. } \\
\text { [57] }\end{array}$ & $\begin{array}{c}\text { Trombly \& Fortier } \\
\text { [58] }\end{array}$ & $\begin{array}{c}\text { Navarro et al. } \\
\text { [20] }\end{array}$ \\
\hline $\mathrm{Kg} / 0.75 \mathrm{~L}$ & $0.90-2.00$ & $0.65-1.17$ & 1.43 & $1.03-0.617$ & 0.85 \\
\hline
\end{tabular}

Another important outcome of the project at this stage was to realize how relevant to the final CF some particular activities or inputs were, even when their costs were not that significant. Together with the use of particular farming chemical treatments (which had a much higher impact that some organic equivalent products), the LCA showed that an average of $50 \%$ of the unitary CF of a bottle of wine produced came from the bottle itself (in some cases reaching up to $70 \%$ ). This high volume of $\mathrm{CO}_{2}$ emissions comes from the glass production process and may vary considerably from some types of glass to others, with little or no difference in its price. Even though this finding is in line with previous studies $[15,20,56,58]$ it caused a change in the company procurement policies of bottles, which now include the CF associated with the bottle as one of the most important features in its selection.

\subsection{Discussion}

The results of the project can be analyzed from different perspectives and scopes, intertwining environmental and management concerns, production process and supply chain, and internal stakeholders' relationship with external ones.

Regarding the impact on the CF of the referred activities, the results are rather positive not only in terms of reduction but also in terms of aggregated CF. The study of Navarro et al. [20] on different wineries in Spain and south of France, which could be comparable to that of the project, reached a range of $\mathrm{CF}$ between 0.6 to $2.65 \mathrm{~kg}$ per bottle. Although the many differences existing among wineries advise not to compare their $\mathrm{CF}$ results, the data obtained for the project are definitely in the low part of the range. Furthermore, considering that Navarro et al. [20] concluded that through the establishment 
of best practices and better resource consumption wine CF could be of about $0.64 \mathrm{~kg}$ per bottle, the $3.3 \%$ decrease obtained in our project after just one year of implementation is noteworthy.

After the two years of data, and the different results obtained from the LCA, the strong impact that the supply chain has in the product unitary CF became clear. Although the company was already aware of the room for improvement existing in the transport and distribution activities undertaken by the company itself (reducing consumption and/or shifting to electricity, renewables, etc.), finding out how relevant some particular supplies were to the CF brought in a new way to look at the supply chain and a whole new approach to procurement design. Specifically, the strong CF impact that bottles may have within the production process, and the unexpected differences found in $\mathrm{CO}_{2}$-related emissions between equivalent chemical treatments used in vineyards, paved the way to look at the supply chain as an equally important field to measure, reduce and account for $\mathrm{CO}_{2}$ emissions. In this sense, implementing the LCA and MTCA tools has not only helped to reduce the CF of the company, but has also transformed the company into a tractor element for other companies.

From the relational perspective, an indirect outcome of the project, which was not really expected in its original design, was a significant improvement in the relationship between the company and its suppliers, especially the cooperative farmers, both in terms of communication and efficiency. Once engaged in the project, most of these farmers found the application very useful and convenient, becoming more committed to reducing their own energy consumption and that of the company, but also to participate in further initiatives to reduce the environmental impact. On the other side, by having the chance to monitor the activity of the farmers, the technical staff of the company can also notice irregular trends, deviations or room for improvement linked to changes in weather conditions, quality of grape or specific needs of the company for the final product characteristics.

\section{Conclusions}

The case study described in this paper presents an empirical attempt to improve the environmental management of a company, focusing on its carbon footprint, under the approach of Material Flow Cost Accounting (MTCA) for physical and monetary flows along the value chain of the company. The corresponding project was undertaken in a winery company and its supply chain, where a monitoring and accounting system which would systematically record the $\mathrm{CO}_{2}$ emissions of the production process of the product would be deployed and put into practice, allowing for instant control of the carbon footprint of products and of the whole company.

The main objective of the case study presented is to assess the outcomes of the process, and evaluate whether a MTCA system for energy usage and carbon emissions can help in reducing the environmental impact of a company as well as its energy costs.

Results show that the costs and difficulties associated with the implementation of the system and its transfer to suppliers are largely offset by the benefits derived from its use, both in terms of energy savings and carbon emissions reduction. Bringing in employees' attention to the $\mathrm{CO}_{2}$ emissions caused at every stage of the production process produces a change in perception leading to the consideration of the carbon footprint as a costs management topic. Furthermore, results are not limited to energy and emissions reduction, but they extend to other factors such as improved efficiency of equipment and processes, detection of malfunction and excessive consumption, change in procurement policies, better communication with suppliers and better understanding of their own processes, improved corporate image of the company and greater commitment of employees, suppliers and community with the goal of sustainability.

In the long run, the company expects to gain international recognition and a competitive advantage in the most environmentally exigent markets. The possibility of keeping track of carbon emissions per product during the production process, brings in a whole range of opportunities to reduce the carbon footprint, compensate for the carbon emissions, develop a near-to-zero emissions line of products, etc. The winery is now able to report the carbon footprint per product, together with the project results and expectations for the future. 
Overall, the case study relies on a triple bottom line rationale, since it had environmental goals linked to reducing the carbon emissions, social implications associated with the inclusion and empowerment of farmers in the process, and economic objectives, aligned to the reduction in energy costs, the access to new markets and the improvement of the company corporate image. The innovative axis of these three visions from the accounting perspective embedded in the idea of Material Flow Cost Accounting, contributes to both the managerial decision making process and the accountability initiatives which the company may adopt.

In line with this case study, similar projects aiming at introducing MTCA systems in other farming or agro-food industries could help strengthen or expand the results, and serve as stimulus for companies to progress towards environmental sustainability. Accounting of non-monetary items can be a powerful tool to highlight the benefits of a sustainable approach to production. Other models that effectively account for the environmental impact would also be interesting lines of research, so that they can be compared to the model developed in this project, and deliver pros and cons to its deployment.

Author Contributions: All authors have equally contributed to the paper in all its parts. All authors have read and agreed to the published version of the manuscript.

Funding: This paper was made possible by funding from the Spanish Ministry of Economy, Industry and Competitiveness, Project "ECOCIRCULAR" Ref. ECO 2016-74920-C2-1-R and was partially cofinanced by the Regional Government of Aragón within the framework of the Research Group Ref.: S33_20R.

Conflicts of Interest: The authors declare no conflict of interest.

\section{References}

1. Baumast, A.; Pape, J. (Eds.) Betriebliches Nachhaltigkeitsmanagement, 1st ed.; Eugen Ulmer: Stuttgart, Germany, 2013.

2. Nakajima, M.; Kimura, A.; Wagner, B. Introduction of material flow cost accounting (MFCA) to the supply chain: A questionnaire study on the challenges of constructing a low-carbon supply chain to promote resource efficiency. J. Clean. Prod. 2015, 108, 1302-1309. [CrossRef]

3. Dierkes, S.; Siepelmeyer, D. Production and cost theory-based material flow cost accounting. J. Clean. Prod. 2019, 235, 483-492. [CrossRef]

4. Christ, K.L.; Burritt, R.L. Material flow cost accounting: A review and agenda for future research. J. Clean. Prod. 2015, 108, 1378-1389. [CrossRef]

5. Cooper, R.; Slagmulder, R. Supply Chain Development for the Lean Enterprise e Inter-organizational Cost Management; Deselnicu, O.C., Ed.; Productivity, Inc.: Plymouth, MN, USA, 1999.

6. Ruggieri, L.; Cadena, E.; Martínez-Blanco, J.; Gasol, C.M.; Rieradevall, J.; Gabarrell, X.; Gea, T.; Sort, X.; Sánchez, A. Recovery of organic wastes in the Spanish wine industry. Technical, economic and environmental analyses of the composting process. J. Clean. Prod. 2009, 17, 830-838. [CrossRef]

7. Bisson, L.F.; Waterhouse, A.L.; Ebeler, S.E.; Walker, M.A.; Lapsley, J.T. The present and future of the international wine industry. Nat. Cell Biol. 2002, 418, 696-699. [CrossRef]

8. Cordano, M.; Marshall, R.S.; Silverman, M. How do Small and Medium Enterprises Go “Green”? A Study of Environmental Management Programs in the U.S. Wine Industry. J. Bus. Ethics 2010, 92, 463-478. [CrossRef]

9. Christ, K.L.; Burritt, R.L. Critical environmental concerns in wine production: An integrative review. J. Clean. Prod. 2013, 53, 232-242. [CrossRef]

10. Notarnicola, B.; Tassielli, G.; Nicoletti, G.M. Life cycle assessment (LCA) of wine production. In Environmentally-Friendly Food Processing; Mattson, B., Sonesson, U., Eds.; Woodhead Publishing Ltd.: Cambridge, UK, 2003; pp. 306-326.

11. Mujica, M.; Blanco, G.; Santalla, E. Carbon footprint of honey produced in Argentina. J. Clean. Prod. 2016, 116, 50-60. [CrossRef]

12. Lamastra, L.; Suciu, N.A.; Novelli, E.; Trevisan, M. A new approach to assessing the water footprint of wine: An Italian case study. Sci. Total Environ. 2014, 490, 748-756. [CrossRef] [PubMed]

13. Herath, H.M.I.K.; Green, S.; Singh, R.; Horne, D.; Van Der Zijpp, S.; Clothier, B. Water footprinting of agricultural products: A hydrological assessment for the water footprint of New Zealand's wines. J. Clean. Prod. 2013, 41, 232-243. [CrossRef] 
14. Herath, H.M.I.K.; Green, S.; Horne, D.; Singh, R.; McLaren, S.J.; Clothier, B. Water footprinting of agricultural products: Evaluation of different protocols using a case study of New Zealand wine. J. Clean. Prod. 2013, 44, 159-167. [CrossRef]

15. Vázquez-Rowe, I.; Rugani, B.; Benetto, E. Tapping carbon footprint variations in the European wine sector. J. Clean. Prod. 2013, 43, 146-155. [CrossRef]

16. Santalla, E.; Córdoba, V.; Blanco, G. Greenhouse gas emissions from the waste sector in Argentina in businessas-usual and mitigation scenarios. J. Air Waste Manag. Assoc. 2013, 63, 909-917. [CrossRef] [PubMed]

17. Point, E.; Tyedmers, P.; Naugler, C. Life cycle environmental impacts of wine production and consumption in Nova Scotia, Canada. J. Clean. Prod. 2012, 27, 11-20. [CrossRef]

18. Aranda, A.; Zabalza, I.; Scarpellini, S. Economic and environmental analysis of the wine bottle production in Spain by means of life cycle assessment. Int. J. Agric. Resour. Gov. Ecol. 2005, 4, 178-191. [CrossRef]

19. Nowak, L.I.; Washburn, J.H. Building Brand Equity: Consumer Reactions to Proactive Environmental Policies by the Winery. Int. J. Wine Mark. 2002, 14, 5-19. [CrossRef]

20. Navarro, A.; Puig, R.; Kılıç, E.; Penavayre, S.; Fullana-I-Palmer, P. Eco-innovation and benchmarking of carbon footprint data for vineyards and wineries in Spain and France. J. Clean. Prod. 2017, 142, 1661-1671. [CrossRef]

21. Frigon, A.; Doloreux, D.; Shearmur, R. Drivers of eco-innovation and conventional innovation in the Canadian wine industry. J. Clean. Prod. 2020, 275, 124115. [CrossRef]

22. Smith, D.M. Sustainable viticulture and winery practices in California: What is it, and do customers care? Int. J. Wine Res. 2009, 189. [CrossRef]

23. Bastianoni, S.; Donati, A.; Piccini, A. How to Measure the Sustainability of an Area? The SPIn-Eco Project and the Sustainability of the Province of Siena. In Transactions on Ecology and the Environment Vol 63; WIT Press. 2003; ISSN 1743-3541. Available online: www.witpress.com (accessed on 25 November 2020).

24. Kokubu, K.; Tachikawa, H. Material flow cost accounting: Significance and practical approach. In Handbook of Sustainable Engineering; Kauffman, J., Lee, K.-M., Eds.; Springer: Dordrecht, The Netherlands, 2013; pp. 351-369.

25. Lang, C.; Heubach, D.; Loew, T. Using software systems to support environmental accounting instruments. In Implementing Environmental Management Accounting; Rikhardsson, P.M., Bennett, M., Bouma, J.J., Schaltegger, S., Eds.; Springer: Berlin/Heidelberg, Germany, 2005; pp. 143-168.

26. International Organization for Standardization (ISO). ISO 14051: Environmental Management: Material Flow Cost Accounting: General Framework; International Organization for Standardization: Geneva, Switzerland, 2011.

27. Prox, M. Material Flow Cost Accounting Extended to the Supply Chain - Challenges, Benefits and Links to Life Cycle Engineering. Procedia CIRP 2015, 29, 486-491. [CrossRef]

28. Jasch, C. Environmental management accounting: Comparing and linking requirements at micro and macro levels e a practitioner's view. In Environmental Management Accounting and Supply Chain Managemen; Burritt, R.L., Schaltegger, S., Bennett, M., Pohjola, T., Csutora, M., Eds.; Springer: Berlin/Heidelberg, Germany, 2011; pp. 255-277.

29. Scavone, G.M. Challenges in internal environmental management reporting in Argentina. J. Clean. Prod. 2006, 14, 1276-1285. [CrossRef]

30. Günther, E.; Rieckhof, R.; Schrack, D.; Walz, M. Materialflusskostenrechnung im Lichte eines klassischen Kostenrechnungsverständnisses e versuch einer Annäherung. In Nachhaltiges Entscheiden e Beitr€age zum Multiperspektivischen Performancemanagement von Wertschöpfungsprozessen; Ahn, H., Clermont, M., Sourcen, R., Eds.; Springer Gabler: Wiesbaden, Germany, 2016; pp. 149-174.

31. Ene, S.A.; Teodosiu, C.; Robu, B.; Volf, I. Water footprint assessment in the winemaking industry: A case study for a Romanian medium size production plant. J. Clean. Prod. 2013, 43, 122-135. [CrossRef]

32. Pawsey, N. Water Management Accounting and the Wine Supply Chain: Empirical Evidence from Australia. Soc. Environ. Account. J. 2015, 35, 195. [CrossRef]

33. Christ, K.L. Water management accounting and the wine supply chain: Empirical evidence from Australia. Br. Account. Rev. 2014, 46, 379-396. [CrossRef]

34. Arzoumanidis, I.; Fullana-I-Palmer, P.; Raggi, A.; Gazulla, C.; Raugei, M.; Benveniste, G.; Anglada, M. Unresolved issues in the accounting of biogenic carbon exchanges in the wine sector. J. Clean. Prod. 2014, 82, 16-22. [CrossRef] 
35. Bosco, S.; Di Bene, C.; Galli, M.; Remorini, D.; Massai, R.; Bonari, E. Soil organic matter accounting in the carbon footprint analysis of the wine chain. Int. J. Life Cycle Assess. 2013, 18, 973-989. [CrossRef]

36. Hoekstra, A.Y.; Chapagain, A.K.; Aldaya, M.M.; Mekonnen, M.M. The Water Footprint Assessment Manual: Setting the Global Standard; Water Footprint Network; Earthscan Publishing: London, UK, 2011.

37. Neto, B.; Dias, A.C.; Machado, M. Life cycle assessment of the supply chain of a Portuguese wine: From viticulture to distribution. Int. J. Life Cycle Assess. 2012, 18, 590-602. [CrossRef]

38. Quinteiro, P.; Dias, A.C.; Pina, L.; Neto, B.; Ridoutt, B.G.; Arroja, L. Addressing the freshwater use of a Portuguese wine ('vinho verde') using different LCA methods. J. Clean. Prod. 2014, 68, 46-55. [CrossRef]

39. Villanueva-Rey, P.; Vázquez-Rowe, I.; Otero, M.; Moreira, M.T.; Feijoo, G. Accounting for time-dependent changes in GHG emissions in the Ribeiro appellation (NW Spain): Are land use changes an important driver? Environ. Sci. Policy 2015, 51, 215-227. [CrossRef]

40. Niccolucci, V.; Galli, A.; Kitzes, J.; Pulselli, R.M.; Borsa, S.; Marchettini, N. Ecological Footprint analysis applied to the production of two Italian wines. Agric. Ecosyst. Environ. 2008, 128, 162-166. [CrossRef]

41. Rugani, B.; Vázquez-Rowe, I.; Benedetto, G.; Benetto, E. A comprehensive review of carbon footprint analysis as an extended environmental indicator in the wine sector. J. Clean. Prod. 2013, 54, 61-77. [CrossRef]

42. Quezada, R.; Hsieh, T.; Valderrama, J.O. Determination of the carbon footprint using the method composed of financial accounts (MC3) for a wine company in Chile. Inf. Tecnol. 2013, 24, 3-14. [CrossRef]

43. Viers, J.H.; Williams, J.N.; Nicholas, K.A.; Barbosa, O.; Kotzé, I.; Spence, L.; Webb, L.B.; Merenlender, A.; Reynolds, M. Vinecology: Pairing wine with nature. Conserv. Lett. 2013, 6, 287-299. [CrossRef]

44. Bosco, S.; Di Bene, C.; Galli, M.; Remorini, D.; Massai, R.; Bonari, E. Greenhouse gas emissions in the agricultural phase of wine production in the Maremma rural district in Tuscany, Italy. Ital. J. Agron. 2011, 6, 93-100. [CrossRef]

45. Benedetto, G.; Rugani, B.; Vázquez-Rowe, I. Rebound effects due to economic choices when assessing the environmental sustainability of wine. Food Policy 2014, 49, 167-173. [CrossRef]

46. Marco, M.; Moneva, J.M.; Scarpellini, S. Environmental disclosure and eco-innovation interrelation. The case of Spanish firms. Span. Account. Rev. 2019, 22, 71-85.

47. Radu, A.L.; Olaru, O.; Dimitriu-Caracota, M.; Banacu, C.S. Ecological footprint analysis: Towards a projects evaluation model for promoting sustainable development. Vision 2020: Innovation, Development Sustainability, and Economic Growth. In Proceedings of the 21st International Business Information Management Association Conference, IBIMA, Vienna, Austria, 27-28 June 2013; Volume 2, pp. 399-407.

48. Lesschaeve, I.; Bowen, A.; Bruwer, J. Determining the Impact of Consumer Characteristics to Project Sensory Preferences in Commercial White Wines. Am. J. Enol. Vitic. 2012, 63, 487-493. [CrossRef]

49. Burritt, R.; Schaltegger, S. Eco-efficiency in corporate budgeting. Environ. Manag. Heal. 2001, 12, $158-174$. [CrossRef]

50. Stechemesser, K.; Guenther, E. Carbon accounting: A systematic literature review. J. Clean. Prod. 2012, 36, 17-38. [CrossRef]

51. Bonamente, E.; Scrucca, F.; Asdrubali, F.; Cotana, F.; Presciutti, A. The water footprint of the wine industry: Implementation of an assessment methodology and application to a case study. Sustainability 2015, 7, 12190-12208. [CrossRef]

52. Viana, R.C.; Rodrigues, L.L. A special accounting treatment for regulated industries? The case of the port wine industry. J. Wine Res. 2006, 17, 11-34. [CrossRef]

53. Aparicio, J.; Borras, F.; Pastor, J.T.; Vidal, F. Accounting for slacks to measure and decompose revenue efficiency in the Spanish Designation of Origin wines with DEA. Eur. J. Oper. Res. 2013, 231, 443-451. [CrossRef]

54. Van der Zanden, G.J. The Truth about $\mathrm{CO}_{2}$ Emissions in the Wine Industry. Viña De Martino, Reinventing Chile, CHILE 2009. Available online: http://www.txb-finewines.com/upload/The_truth_about_CO2_emissions_in_ the_wine_industry_April_2009_223.pdf (accessed on 25 November 2020).

55. Casini, L.; Marone, E.; Scozzafava, G. Management accounting in the winegrowing sector: Proposal and development of an "Ad Hoc" control system. Qual. Access Success 2014, 15, 70-73.

56. Scrucca, F.; Bonamente, E.; Rinaldi, S. Carbon footprint in the wine industry. In Environmental Carbon Footprints: Industrial Case Studies; Elsevier: Amsterdam, The Netherlands, 2017; pp. 161-196. [CrossRef] 
57. Rinaldi, S.; Bonamente, E.; Scrucca, F.; Merico, M.C.; Asdrubali, F.; Cotana, F. Water and Carbon Footprint of Wine: Methodology Review and Application to a Case Study. Sustainability 2016, 8, 621. [CrossRef]

58. Trombly, A.J.; Fortier, M.P. Carbon Footprint of Wines from the Finger Lakes Region in New York State. Sustainability 2019, 11, 2945. [CrossRef]

Publisher's Note: MDPI stays neutral with regard to jurisdictional claims in published maps and institutional affiliations.

(C) 2020 by the authors. Licensee MDPI, Basel, Switzerland. This article is an open access article distributed under the terms and conditions of the Creative Commons Attribution (CC BY) license (http://creativecommons.org/licenses/by/4.0/). 